\title{
Assessment of Surface Water Quality in Hyderabad Lakes by Using Multivariate Statistical Techniques, Hyderabad-India
}

\author{
A. Sridhar Kumar ${ }^{1}$, A. Madhava Reddy ${ }^{2}$, L. Srinivas ${ }^{3} \&$ P. Manikya Reddy ${ }^{4}$ \\ ${ }^{1}$ Department of Environmental Science, Osmania University, Hyderabad, Telangana State, India \\ ${ }^{2}$ Environmental Specialist, Hyderabad, Telangana State, India \\ ${ }^{3}$ Research Scholar, Department of Botany, Osmania University of Hyderabad, India \\ ${ }^{4}$ Professor, Department of Botany, Osmania University-Hyderabad, India
}

Correspondence: A. Sridhar Kumar, Department of Environmental Science, Osmania University, Hyderabad, Telangana State, India. E-mail: meetsreedhar1@gmail.com

\author{
Received: January 2, 2015 Accepted: January 13, 2015 Online Published: March 2, 2015 \\ doi:10.5539/ep.v4n2p14 URL: http://dx.doi.org/10.5539/ep.v4n2p14
}

\begin{abstract}
Multivariate statistical techniques such as cluster analysis (CA), principle component analysis (PCA), factor analysis (FA) were applied for the evolution of temporal variations and the interpretation of large complex water quality data set of the Hyderabad city, generating during year 2013-14 monitoring of 16 parameters at 23 different sites of an average depth of $1 \mathrm{~m}$. Hierarchical clustering analysis (CA) is first applied to distinguish the three general water quality patterns among the stations. Data set thus obtained was treated using R-mode factor analysis (FA) and followed by principle component analysis (PCA). Factor analysis identified five factors responsible for data structure explaining $75 \%$ of total variance and allowed to group selected parameters according to common futures. WT, EC, TSS and Na were associated and controlled by mixed origin with similar contribution from natural and anthropogenic sources. Whereas $\mathrm{NO}_{3}, \mathrm{PO}_{4}, \mathrm{SO}_{4}, \mathrm{FC}, \mathrm{TC}, \mathrm{F}^{-}, \mathrm{K}$ and $\mathrm{B}$ were derived from anthropogenic sources.
\end{abstract}

Keywords: cluster analysis, factor analysis, water quality, natural pollution, anthropogenic pollution

\section{Introduction}

The protection and restoration of urban lakes and wetlands, urban lakes are in extremely poor condition in Hyderabad, within last 12 years, Hyderabad has lost 3245 ha. area of its water in the form of lakes and ponds. There are endless examples in India that shows such devastating state of urban water bodies (Sridhar Kumar et al, 2014). Almost all urban water bodies in India are suffering because of pollution and are used for disposing untreated local sewage, industrial waste water and solid waste, and in many cases the water bodies have been ultimately turned into landfills. Point and non point sources of pollution degrade surface and ground water and impair their use for drinking, industrial, agricultural, recreation or other purposes (Carpenter et al., 1998; Howarth et al., 1996). A number of point and non point sources contaminate the water bodies by adding the excess nutrients and heavy metals. Over the years their capacities went on decreasing by rapid urbanization, encroachments into lake areas and increased sedimentation resulting from the high human interference in the catchment area (Ramachandraiah and Prasad, 2004). Urbanization increases in population density and the intensification of agricultural activities in the upstream areas is among the main causes of water pollution. Therefore, researchers have been paying more attention to the effects of natural and human activities on water quality, in particular, the key contributors of human activities to nutrients and heavy metals. The discharge of effluents and associated toxic compounds into aquatic ecosystem represents an ongoing environmental problem due to their possible impact on communities in the receiving aquatic water and a potential effect on human health (Abbas Alkarkhi et al., 2008). Further these materials enter the surface water resulting in pollution of irrigation and drinking water. Although, the government of India's (GOI, 1992) policy statement on abatement of pollution at source (GoI, 1992).

Many investigations have been conducted on anthropogenic contaminants of ecosystems. Because of the spatial and temporal variation in water quality conditions, a monitoring program which provides a representative and reliable estimation of the quality of surface waters is necessary (Dixon and Chiswell 1996). The monitoring 
results produce a large and complicated data matrix that is difficult to interpret to draw meaningful conclusions. Multivariate statistical techniques are powerful tools for analyzing large numbers of samples collected in surveys, classifying assemblages and assessing human impacts on water quality and ecosystem conditions.

The application of different multivariate statistical techniques, such as principal component analysis (PCA), factor analysis (FA), and cluster analysis (CA), assists in the interpretation of complex data matrices for a better understanding of water quality and ecological status of the studied system. These techniques provide the identification of possible factors/sources that affect water environmental systems and offer a valuable tool for reliable management of water resources as well as rapid solution for pollution issues (Palma et al., 2010; Morales et al., 1999). Multivariate statistical techniques have been widely adopted to analyze and evaluate surface and freshwater water quality, and are useful to verify temporal and spatial variations caused by natural and anthropogenic factors linked to seasonality (Wunderlin et al., 2001; Simenov et al., 2003).

The study area, Hyderabad consists of urban lakes situated on the Deccan Plateau at a height of 1788 feet above sea level, located at $17^{\circ} 22^{\prime}$ of northern latitude and $78^{\circ} 29^{\prime}$ of the eastern longitude with an area of $7,100 \mathrm{sq} \mathrm{km}$. The city has been dotted with a number of lakes and almost all the lakes were artificially created, often some centuries back, by constructing bunds and dams in the downstream area of micro-catchments. From upstream of the reservoir to the downstream, these lakes form a cascading system with limited storage space. (Fig-1). Normal rainfall is $786.8 \mathrm{~mm}$ which increases from northwest to southeast. The mean maximum and minimum temperature vary from $40^{\circ}$ to $14^{\circ} \mathrm{C}$. The city is drained by river Musi and the drainage pattern is of dendritic and rectangular type.

\section{Materials and Methods}

In the present study, the data obtained during the year 2013-14, is subjected to different multivariate statistical techniques to extract about the similarities or dissimilarities between sampling stations, identification of water quality variables responsible for spatial and temporal variations in lakes water quality, the hidden factors explaining the structure of the data base and the influence of possible sources (natural and anthropogenic) on the water quality parameters of the lake basins.

The author has conducted a water quality survey during the year 2013-14 on few lakes \& tanks because of either increase in the levels of critical parameters or on the point of conservation so as to improve the water quality and its management. These lakes have an average depth of $1 \mathrm{~m}$ and having the major human activities like cattle wading, boating, fishing, and the agriculture is melon farming, vegetables and paragrass. The major water quality issues are pathogenic (Bacteriological) pollution, oxygen depleting organic pollution, agricultural runoff, salinity and trace elements. 


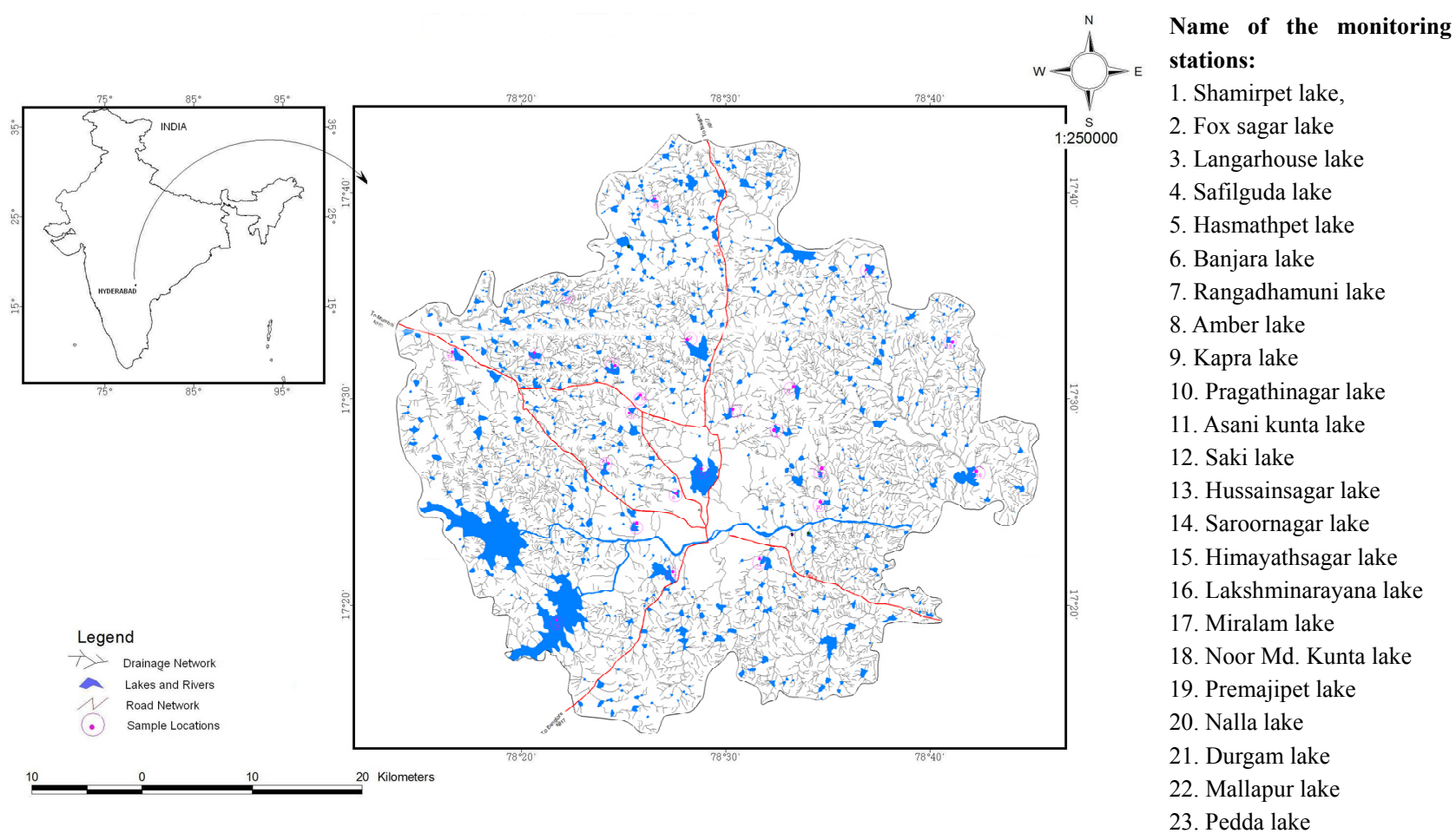

Figure 1. Map of study area and water quality monitoring stations (listed 1-23) in Hyderabad basin

\subsection{Monitored Parameters and Analytical Methods}

The data generated about 23 water quality monitoring stations, comprising 16 water quality parameters monitored during the year (2013-14). The selected water quality parameters, their units and methods of analysis are summarized in Table 1.The author has sampled preserved and analyzed all the water quality parameters as per Indian inland surface water quality standards. All the samples were collected at center of the lake location. The depth of the sample is subsurface $0.5 \mathrm{~m}$ below the water surface. The basic statistics of the measured one year data set on Hyderabad lakes water quality are summarized in Table 2.

Table 1 . The water quality parameters, their units and methods of analysis

\begin{tabular}{llll}
\hline Parameters & Abbreviations & Units & Analytical methods \\
\hline Temperature & $\mathrm{WT}$ & ${ }^{\circ} \mathrm{C}$ & Mercury thermometer \\
Total suspended solids & $\mathrm{TSS}$ & $\mathrm{mg} / 1$ & Dried at 103 to $105^{\circ} \mathrm{C}$ \\
Biochemical oxygen demand & $\mathrm{BOD}$ & $\mathrm{mg} / 1$ & Winkler azide \\
Electrical conductivity & $\mathrm{EC}$ & $\mu \mathrm{S} / \mathrm{cm}$ & Electrometric \\
Dissolved oxygen & $\mathrm{DO}$ & $\mathrm{mg} / 1$ & Winkler azide \\
Fluoride & $\mathrm{F}-$ & $\mathrm{mg} / 1$ & Ion selective electrode \\
Nitrate & $\mathrm{NO}_{3}$ & $\mathrm{mg} / 1$ & Nitrate electrode \\
Phosphate & $\mathrm{PO}_{4}$ & $\mathrm{mg} / 1$ & Stannous chloride \\
Sulphate & $\mathrm{SO}_{4}$ & $\mathrm{mg} / 1$ & Nephelometry \\
Boron & $\mathrm{B}$ & $\mathrm{mg} / 1$ & Spectorphotometric \\
Sodium & $\mathrm{Na}$ & $\mathrm{mg} / 1$ & Flame emission photometric \\
Sodium $\%$ & $\% \mathrm{Na}$ & $\mathrm{Meq} / 1$ & Atomic absorption spectrometry \\
Potassium & $\mathrm{K}$ & $\mathrm{Mg} / 1$ & Flame emission photometric \\
Sodium absorption ratio & $\mathrm{SAR}$ & $\mathrm{Meq} / 1$ & Atomic absorption spectrometry \\
Fecal coliform & $\mathrm{FC}$ & $\mathrm{MPN} / 100 \mathrm{ml}$ & Multiple tube dilution \\
Total coliform & $\mathrm{TC}$ & $\mathrm{MPN} / 100 \mathrm{ml}$ & Multiple tube dilution \\
\hline
\end{tabular}


Table 2. Mean and S.D. of different lakes water quality parameters at various locations during the year 2013-14

Stations (1 to 23)

\begin{tabular}{|c|c|c|c|c|c|c|c|c|c|c|c|c|c|c|c|c|c|c|c|c|c|c|c|c|}
\hline & & & & & & & & & & & & tation & (1) 23 & & & & & & & & & & & \\
\hline & meters & & & & & & & & & & & & & & & & & & & & & & & \\
\hline & & 1 & 2 & 3 & 4 & 5 & 6 & 7 & 8 & 9 & 10 & 11 & 12 & 13 & 14 & 15 & 16 & 17 & 18 & 19 & 20 & 21 & 22 & 23 \\
\hline WT & Mean & 26.00 & 27.30 & 27.70 & 29.70 & 27.00 & 25.30 & 28.70 & 28.30 & 26.70 & 28.00 & 27.30 & 27.70 & 26.30 & 25.00 & 25.30 & 29.00 & 24.30 & 26.70 & 26.70 & 25.00 & 25.70 & 29.70 & 30.00 \\
\hline & S.D & 1.73 & 0.58 & 0.58 & 0.58 & 1.00 & 2.31 & 0.58 & 0.58 & 1.15 & 0.00 & 3.06 & 2.31 & 2.31 & 1.73 & 2.31 & 0.00 & 2.31 & 1.15 & 1.15 & 3.46 & 1.15 & 0.58 & 0.00 \\
\hline TSS & Mean & 13.00 & 33.00 & 10.70 & 17.70 & 13.30 & 14.00 & 12.30 & 16.00 & 16.70 & 16.70 & 410.0 & 19.30 & 37.70 & 31.70 & 7.00 & 16.70 & 11.00 & 25.30 & 38.00 & 20.70 & 24.30 & 17.30 & 28.00 \\
\hline & S.D & 5.57 & 29.31 & 4.16 & 7.77 & 1.53 & 5.29 & 8.50 & 3.00 & 5.13 & 2.31 & 190.0 & 16.17 & 39.37 & 13.87 & 3.61 & 6.03 & 1.73 & 11.02 & 10.58 & 10.26 & 7.09 & 1.15 & 10.39 \\
\hline BOD & Mean & 37.70 & 59.00 & 54.30 & 47.30 & 41.70 & 53.00 & 50.30 & 29.30 & 25.30 & 33.30 & 74.30 & 6.70 & 43.00 & 62.30 & 13.70 & 28.30 & 34.00 & 114.7 & 117.7 & 74.70 & 28.00 & 51.30 & 43.30 \\
\hline & S.D & 22.28 & 13.53 & 28.92 & 6.43 & 17.56 & 23.81 & 19.50 & 9.02 & 7.02 & 16.65 & 82.86 & 3.24 & 30.32 & 19.14 & 9.81 & 10.60 & 19.16 & 83.58 & 89.76 & 38.28 & 16.37 & 24.85 & 7.64 \\
\hline EC & Mean & 626 & 1947 & 1117 & 1699 & 1443 & 918 & 1308 & 1386 & 1548 & 1374 & 9350 & 1948 & 1207 & 1542 & 420 & 1697 & 1291 & 1991 & 5862 & 1604 & 1393 & 1657 & 1965 \\
\hline & S.D & 126 & 460 & 478 & 292 & 151 & 106 & 160 & 193 & 193 & 258 & 214 & 5534 & 504 & 321 & 132 & 70 & 323 & 303 & 165 & 3699 & 185 & 277 & 108 \\
\hline DO & Mean & 4.60 & 4.00 & 0.60 & 1.90 & 4.10 & 1.30 & 3.50 & 5.40 & 3.00 & 5.40 & 0.30 & 6.00 & 0.60 & 1.30 & 5.10 & 5.90 & 0.60 & 2.00 & 0.60 & 1.10 & 0.20 & 1.80 & 1.30 \\
\hline & S.D & 1.45 & 0.47 & 0.55 & 0.25 & 3.23 & 1.81 & 1.59 & 0.10 & 0.85 & 1.74 & 0.35 & 0.21 & 1.10 & 1.10 & 0.66 & 1.11 & 0.98 & 3.18 & 1.10 & 1.22 & 0.29 & 0.68 & 0.45 \\
\hline F- & Mean & 1.00 & 1.60 & 1.20 & 1.90 & 1.20 & 1.60 & 0.80 & 1.20 & 1.60 & 1.00 & 0.80 & 0.50 & 1.20 & 0.90 & 0.30 & 1.10 & 1.20 & 2.30 & 1.10 & 1.40 & 1.10 & 1.50 & 1.70 \\
\hline & S.D & 0.36 & 0.85 & 0.78 & 0.95 & 0.46 & 1.00 & 0.31 & 0.21 & 1.12 & 0.40 & 0.04 & 0.02 & 0.75 & 0.61 & 0.32 & 0.56 & 0.60 & 0.44 & 0.72 & 0.32 & 0.72 & 0.64 & 0.61 \\
\hline NO3 & Mean & 10.90 & 5.40 & 15.70 & 11.70 & 28.80 & 12.20 & 35.00 & 19.00 & 2.20 & 24.80 & 22.70 & 16.30 & 19.60 & 11.40 & 0.60 & 8.30 & 4.20 & 33.20 & 6.50 & 75.00 & 32.70 & 48.00 & 13.70 \\
\hline & S.D & 5.52 & 4.37 & 8.92 & 7.59 & 6.88 & 5.65 & 2.19 & 13.23 & 1.04 & 5.25 & 11.02 & 8.08 & 17.89 & 3.99 & 0.35 & 1.57 & 3.36 & 33.46 & 3.77 & 39.74 & 11.20 & 23.12 & 1.79 \\
\hline PO4 & Mean & 0.20 & 0.30 & 2.50 & 1.80 & 2.00 & 1.70 & 3.40 & 3.10 & 3.20 & 3.30 & 0.70 & 0.30 & 4.10 & 2.10 & 0.10 & 2.60 & 1.80 & 1.70 & 1.00 & 3.30 & 3.30 & 3.00 & 0.50 \\
\hline & S.D & 0.06 & 0.17 & 1.22 & 1.36 & 1.65 & 1.46 & 1.47 & 1.18 & 0.09 & 1.58 & 0.58 & 1.00 & 0.29 & 2.07 & 0.05 & 1.75 & 1.15 & 1.01 & 0.26 & 0.58 & 1.61 & 1.53 & 0.46 \\
\hline SO4 & Mean & 23.70 & 72.30 & 57.70 & 61.00 & 62.30 & 52.70 & 115.3 & 67.70 & 70.70 & 70.70 & 499.3 & 38.70 & 94.30 & 99.30 & 30.70 & 80.00 & 67.70 & 176.7 & 659.7 & 97.30 & 74.70 & 96.30 & 96.70 \\
\hline & S.D & 16.62 & 11.15 & 19.35 & 7.94 & 10.50 & 17.56 & 22.94 & 3.79 & 28.01 & 11.02 & 99.90 & 9.02 & 37.58 & 28.36 & 24.54 & 31.19 & 23.12 & 91.36 & 936.7 & 3.79 & 9.29 & 17.21 & 46.23 \\
\hline B & Mean & 0.70 & 1.80 & 0.50 & 0.40 & 0.60 & 0.60 & 0.80 & 0.80 & 1.20 & 0.60 & 0.30 & 0.00 & 0.70 & 0.60 & 1.00 & 1.10 & 0.40 & 0.30 & 0.50 & 0.70 & 0.70 & 0.90 & 0.30 \\
\hline & S.D & 0.61 & 1.56 & 0.40 & 0.32 & 0.93 & 0.67 & 1.19 & 0.98 & 1.85 & 0.74 & 0.46 & 1.05 & 0.67 & 0.55 & 0.49 & 1.16 & 0.61 & 0.30 & 0.47 & 1.10 & 0.76 & 1.25 & 0.00 \\
\hline $\mathrm{Na}$ & Mean & 70.70 & 220.0 & 136.7 & 170.0 & 170.0 & 82.30 & 140.0 & 233.3 & 183.3 & 176.7 & 931.7 & 256.7 & 139.0 & 163.3 & 43.30 & 216.7 & 115.0 & 240.0 & 293.3 & 193.3 & 160.00 & 190.0 & 190.0 \\
\hline & S.D & 18.01 & 10.00 & 70.24 & 36.06 & 10.00 & 14.64 & 40.00 & 45.83 & 40.41 & 55.08 & 15.28 & 224.3 & 36.37 & 15.28 & 23.18 & 55.08 & 87.89 & 17.32 & 115.9 & 28.87 & 20.00 & 10.00 & 1120. \\
\hline$\% \mathrm{Na}$ & Mean & 41.60 & 54.50 & 49.10 & 44.00 & 47.60 & 46.60 & 46.90 & 53.40 & 49.00 & 50.90 & 61.50 & 62.40 & 49.40 & 46.70 & 41.50 & 53.40 & 32.60 & 50.00 & 26.50 & 51.10 & 48.60 & 47.00 & 41.70 \\
\hline & S.D & 3.04 & 6.73 & 5.78 & 2.77 & 4.73 & 7.11 & 7.10 & 9.71 & 10.14 & 8.37 & 6.06 & 17.56 & 2.28 & 3.10 & 13.07 & 5.07 & 22.31 & 3.60 & 5.23 & 6.32 & 3.27 & 2.59 & 18.83 \\
\hline K & Mean & 0.70 & 1.80 & 0.50 & 0.40 & 0.60 & 0.60 & 0.80 & 0.80 & 1.20 & 0.60 & 0.30 & 0.00 & 0.70 & 1.00 & 0.30 & 1.10 & 0.40 & 0.30 & 0.50 & 0.70 & 0.70 & 0.90 & 0.60 \\
\hline & S.D & 0.61 & 1.56 & 0.40 & 0.32 & 0.93 & 0.67 & 1.19 & 0.98 & 1.85 & 0.74 & 1.05 & 0.00 & 0.67 & 0.55 & 0.49 & 1.16 & 0.61 & 0.30 & 0.47 & 1.10 & 0.76 & 1.25 & 0.46 \\
\hline SAR & Mean & 1.70 & 3.60 & 2.60 & 2.50 & 2.80 & 3.10 & 2.50 & 3.40 & 3.00 & 3.10 & 11.20 & 8.10 & 2.60 & 2.60 & 1.30 & 3.40 & 1.80 & 3.40 & 2.10 & 3.20 & 2.70 & 2.90 & 1.70 \\
\hline & S.D & 0.76 & 0.40 & 1.06 & 0.35 & 0.21 & 0.40 & 0.70 & 1.01 & 0.78 & 1.06 & 7.71 & 3.23 & 0.46 & 0.26 & 0.64 & 0.21 & 1.39 & 0.17 & 0.17 & 0.51 & 0.00 & 0.35 & 0.29 \\
\hline $\mathrm{FC}$ & Mean & 290.0 & 600.0 & 866.7 & 800.0 & 766.7 & 666.7 & 400.0 & 340.0 & 450.0 & 283.3 & 100.0 & 37.70 & 966.7 & 283.3 & 115.3 & 483.3 & 873.3 & 566.7 & 1733. & 900.0 & 633.30 & 766.7 & 1156. \\
\hline & S.D & 182.4 & 141.4 & 814.4 & 173.2 & 230.9 & 767.8 & 173.2 & 165.2 & 396.8 & 76.38 & 130.0 & 11.24 & 602.7 & 76.38 & 159.9 & 425.2 & 740.3 & 30.51 & 230.9 & 400.0 & 461.88 & 230.9 & 351.1 \\
\hline TC & Mean & 950.0 & 1300 & 1666. & 1400. & 900.0 & 1193. & 1233. & 816.7 & 800.0 & 866.7 & 343.3 & 223.3 & 1300. & 950.0 & 240.0 & 1083. & 1133. & 1066. & 1900. & 1600. & 883.3 & 1300. & 1333. \\
\hline & S.D & 626. & 424.2 & 700.0 & 346.4 & 461.8 & 704.3 & 635.0 & 682.5 & 700.0 & 635.0 & 309.2 & 37.86 & 519.6 & 626.5 & 233.0 & 894.8 & 808.2 & 472.5 & 519.6 & 0.00 & 725.14 & 519.6 & 115.4 \\
\hline
\end{tabular}

From the table 2, it is observed that, stations 13,19, 20 and 21 are receiving directly untreated waste water from the urbanized catchment and the parameters like Phosphates, Nitrates, Coil forms shows above the prescribed standards, whereas stations 2, 11, 12 and 18 are polluted due to agricultural runoff from the catchment area and the presence of parameters like Boron, Potassium, Conductivity, Sodium, SAR and Fluoride shows the above prescribed standards as per the Central Pollution Control Board (CPCB) standards. 


\section{Data Treatment and Multivariate Statistical Methods}

The surface water quality data sets were subjected through three multivariate techniques: cluster analysis (CA), principle component analysis (PCA) and factor analysis (FA) (Singh et al., 2004; Dong et al., 2010 and Kim et al., 2009). Summary statistics of these data sets were first calculated to evaluate the distributions. FA was applied on standardized data through Z-scale transformation in order to avoid misclassification due to wide difference in data dimensionality (Liu et al., 2003; Kim et al., 2009), standardization tends to increase the influence of variables whose variance is small and vice versa. All the mathematical and statistical computations were made using Statistical Package for Social Sciences SPSS, 1995).

Cluster analysis is group of multivariate techniques whose purpose is to assemble objects based on the characteristic they possess. Hierarchical agglomerative clustering is the most common approach, which provides intuitive similarity relationships between any one sample and the entire data set, and is typically illustrated by a dendrogram (tree diagram) (McKenna, 2003). The Euclidean distance usually gives the similarity between analytical values from the samples (Otto, 1998). In this study hierarchical agglomerative CA was performed on the normalized data set by means of the Wards method, using squared Euclidean distances as a measure of similarity. The Wards method uses an analysis of variance approach to evaluate the distances between clusters in an attempt to minimize the sum of squares (SS) of any two clusters that can be formed at each step. The special variability of water quality in the city determined from CA, using the linkage distance, reported as $D_{\text {link }} / D_{\max }$, which represent the quotient between the linkage distances for particular case divided by the maximal linkage distance. The quotient is then multiplied by the 100 as a way to standardize the linkage distance represented on the y-axis.

\subsection{Factor Analysis/Principal Component Analysis (PCA)}

Factor analysis technique extracts the eigen values and eigen vectors from co-variance matrix of original variables. The principle components (PC) are the uncorrelated (orthogonal) variables obtain by multiplying original correlated variables with eigen vector, which is a list of coefficients (loading or weightings). Thus principal components are weighted linear combinations of original variables. PC provides information on the most meaningful parameters, which describe whole data set affording data reduction with minimum loss of original information (Vega et al., 1998; Helena et al., 2000; Shrestha and Kazama 2007). It is a powerful technique for pattern recognition that attempts to explain the variance of large set of inter-correlated variables and transforming in to a smaller set of independent (uncorrelated) variables (principle component). Factor analysis further reduce the contribution of less significant variables obtained from PCA and the new group of variables known as varifactors, are extracted through rotating the axis defined by PCA. A varifactor can include unobservable, hypothetical, latent variables, while a PC is a linear combination of observable water quality variables (Panda et al., 2006; Davis,1986). PCA of the normalized variables was performed to extract significant PC's and to further reduce the contribution of variables with minor significance. These PC's were subjected to varimax rotation (raw) generating varifactors (Brumelis et al., 2000; Love et al., 2004; Abdul et al., 2005).

\section{Results and Discussions}

\subsection{Spatial Similarity and Size Grouping}

Cluster analysis was used to detect the similarity groups between the sampling sites. It yielded a dendrogram (Fig 2) grouping all 23 sampling sites of the city in to three statistically meaningful clusters at $\left(D_{\text {link }} / D_{\max }\right) \times 100$ $<60$. Since we used hierarchical agglomerative cluster analysis, the number of clusters was also decided by practicality of the results as there is ample information (e.g. land use, location of industries etc.) available on the study sites. The results indicate that the CA technique is useful in offering reliable classification of surface water in the whole region and will make it possible to design a future spatial sampling strategy in an optimal manner, which can reduce the number of sampling stations and associated cost. 


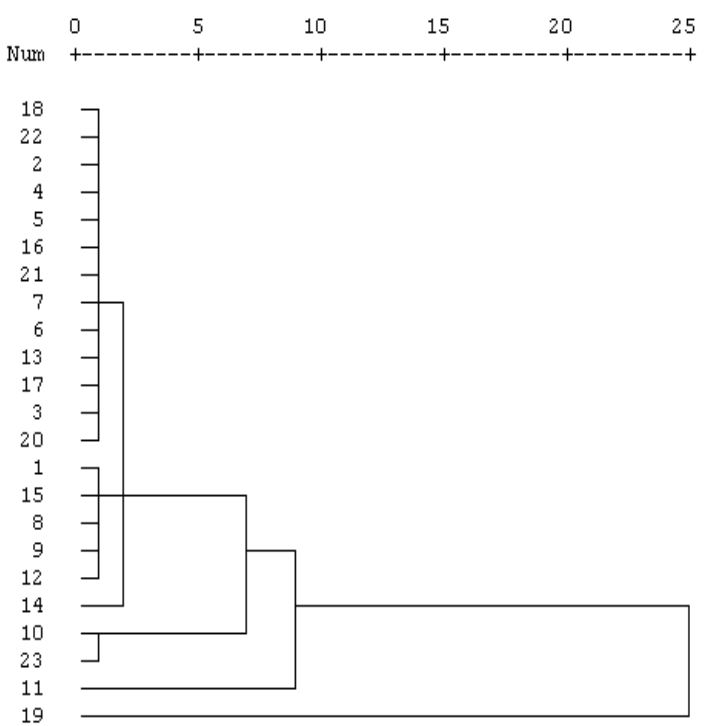

Figure 2. Dendrogram showing clustering of sampling sites according to water quality characteristics

The main descriptive statistics are shown in table 3. Statistical treatment of these data indicates their association and grouping with five factors in water bodies (Table 4). The presence of phosphate and nitrate in most of the sample stations were recorded high. Phosphate it varies from 0.00 to $4.85 \mathrm{mg} / 1$ with an average of $1.99 \mathrm{mg} / \mathrm{l}$. majority of the sample stations ( 16 out of 23) the phosphate recoded above the permissible limits of 1 or above $1.00 \mathrm{mg} / \mathrm{l}$. Nitrate it varies from 0.20 to $112.00 \mathrm{mg} / \mathrm{l}$ with an average of $19.91 \mathrm{mg} / \mathrm{l}$. sample stations $20,21,22$ and 23 were recorded above the permissible limit of $45 \mathrm{mg} / \mathrm{l}$. Phosphates are often considered a primary limiting element and Nitrates considered secondary limiting element in most of the lakes, and these concentrations are positively correlated in lakesIt was observed that the other high values of TSS, Conductivity, Na, SAR, F Coli, T Coli, $\mathrm{SO}_{4}, \mathrm{~F}-, \mathrm{K}$, Temperature and $\mathrm{B}$ due to point and non point sources which may be attributed to the industrial and agricultural activities.

Table 3. Descriptive statistical data of lakes water

\begin{tabular}{|c|c|c|c|c|c|c|c|c|c|c|c|c|c|c|c|c|}
\hline & WT & TSS & BOD & EC & DO & F- & $\mathrm{NO}_{3}$ & $\mathrm{PO}_{4}$ & $\mathrm{SO}_{4}$ & B & $\mathrm{Na}$ & Sodium \% & $\mathbf{K}$ & SAR & F. Coli & T. Coli \\
\hline Mean & 27.10 & 36.97 & 48.84 & 1969.54 & 2.70 & 1.23 & 19.91 & 1.99 & 120.23 & 0.67 & 205.01 & 47.65 & 32.38 & 3.27 & 612.34 & 1061.03 \\
\hline Median & 28.00 & 18.00 & 40.00 & 1511.00 & 2.15 & 1.10 & 15.00 & 1.72 & 72.00 & 0.30 & 180.00 & 49.00 & 30.00 & 2.70 & 500.00 & 1300.00 \\
\hline SD & 2.09 & 87.52 & 39.76 & 2200.17 & 2.26 & 0.67 & 20.18 & 1.55 & 220.31 & 0.82 & 259.73 & 10.89 & 18.00 & 2.62 & 500.59 & 622.37 \\
\hline Minimum & 23.00 & 4.00 & 3.00 & 361.00 & 0.00 & 0.10 & 0.20 & 0.00 & 6.00 & 0.00 & 0.00 & 6.80 & 6.00 & 0.20 & 20.00 & 50.00 \\
\hline Maximum & 30.00 & 600.00 & 218.00 & 15740.00 & 7.10 & 2.90 & 112.00 & 4.85 & 1741.00 & 3.30 & 2175.00 & 74.00 & 99.00 & 20.00 & 2000.00 & 2500.00 \\
\hline
\end{tabular}


Table 4. Factor analysis of lake water quality data

\begin{tabular}{|c|c|c|c|c|c|c|c|c|c|}
\hline Element & Communality & Eigen & Total variance & Cumulative total variance & Factor 1 & Factor 2 & Factor 3 & Factor 4 & Factor 5 \\
\hline WT & .661 & 4.411 & 27.569 & 27.569 & .172 & -.062 & .018 & .789 & -.064 \\
\hline TSS & .810 & 2.568 & 16.052 & 43.621 & .889 & -.011 & -.088 & -.050 & .096 \\
\hline BOD & .585 & 2.009 & 12.554 & 56.175 & .437 & .571 & -.053 & -.200 & .159 \\
\hline EC & .951 & 1.722 & 10.760 & 66.935 & .918 & .322 & -.052 & -.029 & -.020 \\
\hline DO & .653 & 1.398 & 8.739 & 75.674 & -.160 & -.460 & -.105 & .195 & -.606 \\
\hline F- & .657 & .869 & & & -.056 & .237 & .725 & -.236 & -.129 \\
\hline NO3 & .717 & .650 & & & .026 & -.009 & -.016 & .188 & .825 \\
\hline PO4 & 690 & .626 & & & -.132 & -.039 & .778 & .092 & .240 \\
\hline SO4 & .681 & .473 & & & .503 & .627 & -.139 & -.099 & -.075 \\
\hline B & .682 & .434 & & & -.178 & .093 & -.282 & .713 & .232 \\
\hline $\mathrm{Na}$ & .898 & .309 & & & .940 & .009 & .099 & .065 & .028 \\
\hline $\mathrm{Na} \%$ & .678 & .208 & & & .399 & -.564 & .072 & .342 & .281 \\
\hline K & .868 & .153 & & & .563 & .032 & .717 & -.115 & -.149 \\
\hline SAR & .913 & .101 & & & .906 & -.273 & .017 & .123 & .055 \\
\hline F. Coli & .837 & .040 & & & -.162 & .801 & .303 & .233 & .154 \\
\hline T. Coli & .825 & .030 & & & -.135 & .655 & .364 & .442 & .221 \\
\hline
\end{tabular}

Extraction Method: Principal Component Analysis.

Rotation Method: Varimax with Kaiser Normalization.

\subsection{Factor Analysis}

By factor analysis complex linear correlation between metal concentrations was determined, which enabled interpretation of correlation of elements in the study area. Elements belonging to a given factor were defined by factor matrix after varimax rotation, with those having strong correlations grouped in to factors. Considering the influence they exerted in lakes by determining the distribution of parameters in the study area of Hyderabad, the said multiparameter factor was divided in to two groups: (i) factors with strong scattered anthropogenic influence and (ii) factors caused by predominantly natural processes or other anthropogenic influences. The identification of factors is based on dominant influence. The distribution manner of individual association of parameters in the lake waters was determined by principle component method (results are shown in table 4). Based on eigen values and varimax rotation five factors explained most of the variability (total variance explained was about 75.67\%).

\section{Factor 1}

Factor 1 exhibit $27 \%$ of the total variance of $75 \%$ with positive loading on TSS, Conductivity, Na and SAR. This factor can be attributed to the influence of agricultural activity in the study area. This factor indicates strong association ( $\mathrm{r}=0.6-0.94)$ of TSS, Conductivity, Na and SAR. The high variability in the analytical data obtained is indicative of an external source for these parameters in water bodies. Total suspended solids levels were found to be high in few stations with concentration ranging from 4 to $600 \mathrm{mg} / \mathrm{l}$ with an average of $36.97 \mathrm{mg} / \mathrm{l}$. The high TSS values reported at station 11. This may be due to direct discharge of untreated sewage from the nearby surroundings which was not having the proper diversion facilities and proves that source of TSS is anthropogenic addition.

Conductivity, it varies from 361 to $15740 \mu \mathrm{mhos} / \mathrm{cm}$ at $25^{\circ} \mathrm{C}$ (average of $1969 \mu \mathrm{mhos} / \mathrm{cm}$ ) and permissible limit is $2250 \mu \mathrm{mhos} / \mathrm{cm}$, shows poor quality of water as per water class of irrigation guidelines in India. Na varying from 0.00 to $2175 \mathrm{mg} / \mathrm{l}$ with an average of $205 \mathrm{mg} / \mathrm{l}$. and its tolerance limit is 60 . Sample stations 2, 11 and 19 shows abnormal values greater than background mean distribution of $15740 \mu \mathrm{mhos} / \mathrm{cm}$, and $238 \mathrm{mg} / \mathrm{l}$ is high in the area; high values of conductivity and $\mathrm{Na}$ which are near the vicinity of industrial area and found entry of industrial waste in to the water body. And agricultural runoff from the catchment causing its increase in water body as a point and non point sources of pollution. SAR values vary from 0.2 to 20 with an average of 3.5 and this value comes under water class Excellent to Good as per the irrigation guidelines in India. 


\section{Factor 2}

Factor 2 exhibits $16 \%$ of the total variance with positive loading on fecal coli forms (FC), total coli forms (TC) and $\mathrm{SO}_{4}$. Anthropogenic addition of $\mathrm{FC}$ in the water bodies ranging from (MPN) 20 to 2000/100ml (Most Probable Number) with an average of $612 / 100 \mathrm{ml}$, the criteria as per CPCB surface water, fecal coli form (MPN) $500 / 100 \mathrm{ml}$ desirable and $2500 / 100 \mathrm{~mL}$ maximum permissible limit. TC varies from 50 to $2500 \mathrm{MPN}$ with an average of $1061 \mathrm{MPN}$ were recorded at sample station 19 as against the tolerance limit of $50 \mathrm{MPN} / 100 \mathrm{ml}$. Apart from the widespread nature in the environment, the presence TC may also found due to dumping of solid waste on lake shore area. $\mathrm{SO}_{4}$, it varies from 6 to $1741 \mathrm{mg} / 1$ with average of $120 \mathrm{mg} / \mathrm{l}$. The maximum value for $\mathrm{SO}_{4}$ at sample station 19 (as against the tolerance limit of $400 \mathrm{mg} / \mathrm{l}$ ) are due to entry of untreated industrial and domestic waste water into water body. Hence this factor can be attributed to origin of $\mathrm{FC}, \mathrm{TC}$ and $\mathrm{SO}_{4}$ in the area from anthropogenic source only.

\section{Factor 3}

It exhibits $12 \%$ of the total variance with positive loading on $\mathrm{PO}_{4}, \mathrm{~F}$ - and $\mathrm{K}$. This factor can be attributed to the influence of industrial, municipal waste waters and agricultural runoff found on these parameters in the study area. $\mathrm{PO}_{4}$ varies from $0.0-4.85 \mathrm{mg} / \mathrm{l}$ (average=1.99 mg/l), sample stations 3,4,5,6,7,8,10,11,13,14,17,19,20,21,22, and 23 showing above the tolerance limit of $1 \mathrm{mg} / \mathrm{l}$. At these stations it was found that the entry of untreated industrial and domestic waste waters into water bodies as a point and non point source of pollution. F- Varies from $0.10-2.90 \mathrm{mg} / \mathrm{l} \quad($ average $=1.23 \mathrm{mg} / \mathrm{l})$, above the tolerance limit of $1.5 \mathrm{mg} / \mathrm{l}$ found at stations $2,4,5,6,9,13,14,16,17,18,19,20,21,22$ and 23 , this may be the water bodies receiving high municipal sewage along with the solid waste. $\mathrm{K}$ varies from 6 to $99 \mathrm{mg} / 1$ (average $=32.38 \mathrm{mg} / \mathrm{l}$ ), the tolerance limit is $<10 \mathrm{mg} / 1$, except most of the sample stations were exceeded the limit and principle source of $\mathrm{K}$ may be due to entry of untreated industrial waste and municipal water into lakes.

\section{Factor 4}

Factor 4 exhibit $10.7 \%$ of the total variance and has positive loading on Temperature and Boron. Temperature varies from 23 to $30^{\circ} \mathrm{C}$ with an average of $27.12^{\circ} \mathrm{C}$, and $\mathrm{B}$ from 0 to $3.2 \mathrm{mg} / \mathrm{l}$ (average $=0.71 \mathrm{mg} / \mathrm{l}$ ). Most of the sample stations $1,2,5,7,8,9,10,13,14,16,17,21,22$ and 23 shows more than the irrigation desirable limit of $1 \mathrm{mg} / 1$ and the principle source of $\mathrm{B}$ are mainly from agriculture runoff and it is anthropogenic addition. The contamination due to $\mathrm{B}$ in water body and the values represent non point source pollution as an irrigation return flow from the catchment.

\section{Factor 5}

Factor 5 exhibit $8.73 \%$ of the total variance and has positive loading on $\mathrm{NO}_{3} . \mathrm{NO}_{3}$ concentration varies from 0.20 to $112 \mathrm{mg} / \mathrm{l}$ with an average of $19.91 \mathrm{mg} / \mathrm{l}$. which exceeds the desirable limit of $20 \mathrm{mg} / \mathrm{l}$. This factor can be attributed to the influence of municipal waste waters and agricultural runoff found on these parameters in the study area. Sample stations 3,5,10,11,12,13,18,20,21,22 and 23 show comparatively higher concentration.

\section{Conclusions}

In this study, lakes getting polluted due to uncontrolled point and non point sources of pollution due to lack of proper sewage network. Results of factor analysis performed on 10 parameters and identified five factors controlling their variability in the study area. Multivariate statistical approaches show that the pathogenic (Bacteriological) pollution, organic pollution, salinity and Trace elements are highly polluting the lakes. The migration of pollutants in lakes in the form of untreated effluents in the catchment indicates the point source of pollution. The runoff from the agriculture fields also contributing the lake water pollution. The present study suggests that, the usefulness of multivariate statistical techniques for analysis and interpretation of complex data sets, water quality assessment and identification of pollution factors. Regular water quality monitoring for surface water should be undertaken for identification of pollution sources and understanding spatial variations in water quality for effective water quality management.

\section{Recommendations}

- Keeping in view of the urbanization and industrialization the organizations like municipal bodies need to conserve the water bodies around the Hyderabad.

- The untreated effluents emerging from the catchment must be diverted for maintaining the wholesomeness of the water bodies.

- The present study provides the baseline data for assessment of contaminations in the study area. 
- The lake with sewage treatment plant (STP) was not giving much impact on water quality in lakes without first constructing the diversion sewers.

- Change of land use and construction activity of all types shall be prohibited in all water bodies. Construction should be avoided with in maximum water spread area.

\section{Acknowledgements}

The authors are thankful to M.Satyanarayana, Managing Director, Clinicapro data research center, Hyderabad, for his continuous support and giving technical guidelines on statistical portion to this paper.

\section{References}

Abbas Alkarkhi, F. M., Ismail, N., \&Mat Easa, A. (2008). Assessment of arsenic and heavy metal contents in cockles (Anadara granosa) using multivariate statistical techniques. Journal of Hazardous Materials, 150, 783-789. http://dx.doi.org/10.1016/j.jhazmat.2007.05.035

Abdul-Wahab, S. A., Bakheit, C. S., \& Al-Alawi, S. M. (2005). Principle component and multiple regression analysis in modeling of ground-level zone and factors affecting its concentrations. Environmental Modeling \&Software, 20(10), 1263-1271. http://dx.doi.org/10.1016/j.envsoft.2004.09.001

Brumelis, G., Lapina, L., Nikodemus, O., \& Tabors, G. (2000). Use of an artificial model of monitoring data to aid interpretation of principle component analysis. Environmental Modeling \& Software, 15(8), 755763. http://dx.doi.org/10.1016/S1364-8152(00)00060-8

Carpenter, S. R., Caraco, N. F., Correll, D. L., Howarth, R. W., Sharpley, A. N., \& Smith, V. H. (1998). Nonpoint pollution of surface waters with phosphorus and nitrogen. Ecological Applications, 8, 559568. http://dx.doi.org/10.1890/1051-0761(1998)008[0559:NPOSWW]2.0.CO;2

Davis, J. C. (1986). Statistics and Data Analysis in Geology (2nd ed.). Wiley, New York.

Dixon, W., \& Chiswell, B. (1996). Review of aquatic monitoring program design. Water Research, 30, 1935-1948. http://dx.doi.org/10.1016/0043-1354(96)00087-5

Dong, J. D., Zhang, Y. Y., Zhang, S., Wang, Y. S., Yang, Z. H., \& Wu, M. L. (2010). Identification of temporal and spatial variations of water quality in Sanya Bay, China by three-way principal component analysis. Environ. Earth Sci., 60, 1673-1682. http://dx.doi.org/10.1007/s12665-009-0301-4

GoI. (1992). Policy Statement for Abatement of Pollution. Delhi: Ministry of Environment and Forests, Government of India.

Helena, B., Pardo, R., Vega, M., Barrado, E., Fernandez, J. M., \& Fernandez, I. (2000). Temporal evaluation of ground water composition in an alluvial aquifer (Pisuerga River, Spain) by principle component analysis. Water Research, 34, 807-816. http://dx.doi.org/10.1016/S0043-1354(99)00225-0

Howarth, R. W., Billen, G., Swaney, D., Townsend, A., Jaworski, N., Lajtha, K., ... Zhu, Z. L. (1996). Regional nitrogen budget and riverine N \& P fluxes for the drainages to the North Atlantic Ocean: Natural and human influences. Biogeochemistry, 35, 75-139. http://dx.doi.org/10.1007/BF02179825

Kim, J. H., Choi, C. M., Kim, S. B., \& Kwun, S. K. (2009). Water quality monitoring and multivariate statistical analysis for rural streams in South Korea. Paddy Water Environ, 7, 197-208. http://dx.doi.org/10.1007/s10333-009-0162-1

Liu, C. W., Lin, K. H., \& Kuo, Y. M. (2003). Application of factor analysis in the assessment of groundwater quality in a Blackfoot disease area in Taiwan. Science of the Total Environment, 313, 77-89. http://dx.doi.org/10.1016/S0048-9697(02)00683-6

Love, D., Hallbauer, D., Amos, A., \& Haranova, R. (2004). Factor analysis as a tool in ground water quality management: two southern African case studies. Physics and Chemistry of the Earth, 29, 1135-1143. http://dx.doi.org/10.1016/j.pce.2004.09.027

McKenna, Jr., J. E. (2003). An enhanced cluster analysis programme with bootstrap significance testing for ecological community analysis. Environmental Modeling \& Software, 18(3), 205-220. http://dx.doi.org/10.1016/S1364-8152(02)00094-4

Morales, M. M., Marti, P., Lopis, A., Compos, L., \& Sagrado, S. (1999). An Environmental study by factor analysis of surface seawaters in the gulf of Valenica (Western Medterranean). Analytica Chimca Acta, 394, 109-117. http://dx.doi.org/10.1016/S0003-2670(99)00198-1

Otto, M. (1998). Multivariate methods. In R. Kellner, J. M. Mermet, M. Otto \& H. M. Widmer (Eds.), 
Analytical Chemistry. Wiley-VCH, Weinheim.

Palma, P., Alvarenga, P., Palma, V. L., Fernandes, R. M., Soares, A. M. V. M., \& Barbosa, I. R. (2010). Assessment of anthropogenic sources of water pollution using multivariate statistical techniques: A case study of Alqueva's reservoir, Portugal. Environ. Monit. Assess, 165, 539-552. http://dx.doi.org/10.1007/s10661-009-0965-y

Panda, U. C., Sundaray, S. K., Rath, P., Nayak, B. B., \& Bhatta, D. (2006). Application of factor and cluster analysis for characterization of river and estuarine water systems - a case study: Mahanadhi River (India). Journal of Hydrology, 331(3-4), 434-445. http://dx.doi.org/10.1016/j.jhydrol.2006.05.029

Ramachandraiah, C., \& Prasad, S. (2004). Impact of Urban Growth on Water Bodies. The Case of Hyderabad. Working Paper No. 60. pp no 16-22.

Shrestha, S., \& Kazama, F. (2007). Assessment of surface water quality using multivariate statistical techniques: A case study of the Fuji river basin, Japan. Environmental Modeling and Software, 22(4), 464-475. http://dx.doi.org/10.1016/j.envsoft.2006.02.001

Simeonov, V., Stratis, J. A., Samara, C., Zachariadis, G., Vousta, D., Anthemidis, A., Sofoniou, M., \& Kouimtzis, T. (2003). Assessment of the surface water quality in Northern Greece. Water Research, 37, 4119-4124. http://dx.doi.org/10.1016/S0043-1354(03)00398-1

Singh, K. P., Malik, A., \& Sinha, S. (2005). Water quality assessment and apportionment of pollution sources of Gomti River (India) using multivariate statistical techniques: A case study. Anal. Chim. Acta., 538, 355374. http://dx.doi.org/10.1016/j.aca.2005.02.006

Singh, K. P., Malik, A., Mohan, D., \& Sinha, S. (2004). Multivariate statistical techniques for the evaluation of spatial and temporal variations in water quality of Gomti River (India): A case study. Water Research, 38, 3980-3992. http://dx.doi.org/10.1016/j.watres.2004.06.011

SPSS $^{\circledR}$ (Statistical Package for Social Sciences), version 6.1, USA. Professional Statistics 6.1, 385, Marija J. Norusis/SPSS Inc., Chicago, 1995.

Sridhar Kumar, A., Shnakaraiah, K., Rao., P. L. K. M., \& Sathyanarayana, M. (2014). Assessment of water quality in Hussainsagar lake and its inlet channels using multivariate statistical techniques. International $\begin{array}{lllll}\text { Journal of Scientific \& } & \text { Engineering }\end{array}$ http://dx.doi.org/10.14299/ijser.2014.09.007

Vega, M., Pardo, R., Vega, M., Barrado, E., \& Deban, L. (1998). Assessment of seasonal and polluting effects on the quality of river water by exploratory data analysis, Water Research, 32, 3581-3592. http://dx.doi.org/10.1016/S0043-1354(98)00138-9

Wunderlin, D. A., Diaz, M. P., Ame, M. V., Pesce, S. F., Hued, A. C., \& Bistini, M. A. (2001). Pattern recognition techniques for the evaluation of spatial and temporal variations in water quality. A case study: Suquia River basin (Cordoba-Argentina). Water Research, 35, 2881-2894. http://dx.doi.org/10.1016/S0043-1354(00)00592-3

\section{Copyrights}

Copyright for this article is retained by the author(s), with first publication rights granted to the journal.

This is an open-access article distributed under the terms and conditions of the Creative Commons Attribution license (http://creativecommons.org/licenses/by/3.0/). 